CRITICAL THEORY, DEMOCRACY, AND THE CHALLENGE OF NEOLIBERALISM 
This page intentionally left blank 


\section{Critical Theory, Democracy, and the Challenge of Neoliberalism}

BRIAN CATERINO AND PHILLIP HANSEN

UNIVERSITY OF TORONTO PRESS

Toronto Buffalo London 
(C) University of Toronto Press 2019

Toronto Buffalo London

utorontopress.com

Printed in Canada

ISBN 978-1-4875-0546-2

(2) Printed on acid-free, $100 \%$ post-consumer recycled paper with vegetable-based inks.

\section{Library and Archives Canada Cataloguing in Publication}

Title: Critical theory, democracy, and the challenge of neoliberalism / Brian Caterino and Phillip Hansen.

Names: Caterino, Brian, author. | Hansen, Phillip, 1949- author.

Description: Includes bibliographical references and index.

Identifiers: Canadiana 20190096950 | ISBN 9781487505462 (hardcover)

Subjects: LCSH: Democracy - Philosophy. | LCSH: Critical theory. |

LCSH: Neoliberalism. | LCSH: Liberty - Philosophy. |

LCSH: Frankfurt school of sociology.

Classification: LCC JC423 .C38 2019 | DDC 321.8—dc23

This book has been published with the help of a grant from the Federation for the Humanities and Social Sciences, through the Awards to Scholarly Publications Program, using funds provided by the Social Sciences and Humanities Research Council of Canada.

University of Toronto Press acknowledges the financial assistance to its publishing program of the Canada Council for the Arts and the Ontario Arts Council, an agency of the Government of Ontario.

Canada Council for the Arts
Conseil des Arts du Canada

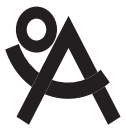

ONTARIO ARTS COUNCIL

CONSEIL DES ARTS DE L'ONTARIO

an Ontario government agency

un organisme du gouvernement de l'Ontario

Funded by the Financé par le Government gouvernement of Canada du Canada 